\title{
A Critique of Feminist Theory
}

\author{
Kathy Lay \\ James G. Daley
}

\begin{abstract}
Objective: Feminism has grown rapidly in the last 40 years as both a multidisciplinary voice advocating for change and an area of scholarship and theorybuilding. A review of empirical articles describes 17 studies that indicate a wide range of applications of feminist theory, but theory is applied primarily as a lens for other issues, rather than to expand theory development. Advocacy and philosophical views seem to overshadow theory development. Suggestions for improving feminist theory are offered.
\end{abstract}

Keywords: Feminism, theory, social work

\section{INTRODUCTION}

Feminist theory has developed as a small part of a very large feminist movement striving to challenge traditions, methodologies, and priorities in all aspects of life. The movement "began a widespread call for a major reassessment of concepts, theories, and methods employed within and across the academic disciplines (Hesse-Biber, 2002, p. 57). The feminist lens was applied to many areas of research. Hesse-Biber and colleagues assert that, "research conducted within a feminist framework is attentive to issues of difference, the questioning of social power, resistance to scientific oppression, and a commitment to political activism and social justice" (Hesse-Biber, Leavy, \& Yaiser, 2004, p. 3).

Many authors have focused on feminist theory and how the conceptualization of the feminist perspective evolved (e.g., Duran, 1998; Donovan, 2000; Evans, 1995) and some authors have emphasized the methodology of feminist theory (e.g., Fonow \& Cook, 1991; Hesse-Biber, Gilmartin, \& Lydenberg, 1999; Hesse-Biber \& Yaiser, 2004). An explosion of articles, books, and conferences has produced a very credible area of scholarship. The next section describes the historical development of feminist theory and how complex the perspective is.

\section{HISTORICAL ANALYSIS OF THEORY DEVELOPMENT}

\section{Feminist Theory: An Overview}

Feminist theory offers a perspective for understanding human behavior in the social environment by centering women and issues that women face in contem-

Kathy Lay, Ph.D. is assistant professor and James G. Daley, Ph.D. is associate professor at Indiana University School of Social Work, Indianapolis, IN 46202-5156.

Copyright $^{\oplus} 2007$ Advances in Social Work Vol. 8 No. 1 (Spring 2007) 49-61.

Indiana University School of Social Work. 
porary society. Feminism reflects "a world view that values women and that confronts systematic injustices based on gender" (Chinn \& Wheeler, 1985, p. 74). A feminist lens asks us to see individuals, groups, family, and organizations in their social, political, economic, ethnic, and cultural contexts. The intersection of these contexts produces the potential for oppression that is rooted in gendered relationships.

Feminist theory is most often associated with the rights of women. This is both simplistic and reductionistic. Many of the human behavior texts offer a precursory review of feminist theory; however, for a comprehensive understanding and application, a broader study is required. There are encompassing concerns inclusive of the discipline's particular epistemological, ontological, and methodological assumptions; however, there is no one monolithic feminist perspective; instead, there are many perspectives, with various theoretical groundings (Andermahr, Lovell, \& Wolkowitz, 1997).

Theory is about understanding our world and everyday experiences. Flax (1999) stated that we all engage in a "systematic analytic approach to everyday experience" (p. 9) and it is done unconsciously. "To theorize, then, is to bring this unconscious process to a conscious level so it can be developed and refined" (p. 9). It is paramount to make theorizing explicit and inclusive of feminist concerns. There are several assumptions associated with feminist theory. Flax (1999) delineated three, with the first being that "men and women have different experiences" (p. 10) in that their worlds are not the same. Some see the goal of feminism as equality, which would include having the same choices and opportunities as men. Feminist theories attempt to explain differences between men and women, call for centering gender and consideration for how gender differences effect human behavior in the context of historical, political, social, and cultural concerns, as well as oppressions that are gender based.

The oppression of women is not simply related to some other social relationship such as a class system. Flax (1999) explained that instead, feminist theory views women's oppression as "a unique constellation of social problems and has to be understood in itself ..." (p. 10). Oppression is seen as a part of the way the world is structured and is not due to pockets of "bad attitudes" (p. 10) or backward traditions, but oppression is embedded in the very socio-economic and political organization of our society. The structure is the patriarchy, which has deep roots in the culture at large (Flax, 1999).

Flax also associated specific goals with feminist theory. These goals include understanding "power differentials between men and women" (p. 10) and power in relationship to the evolution of oppression as well as to bring about social change to end oppression. A central purpose of feminist theory is a "commitment to change oppressive structures and to connect abstract ideas with concrete problems for political action" (p. 11).

Oppression has been defined as the "absence of choices" (Hooks, 1984, p. 5). Women in Western society have choices with regard to everyday human experiences, which include production of resources, reproduction, and the merger of the biological and psychological (Flax, 1999). It is for this reason that some women do not name oppression as a concern or identify as feminists. "The 
absence of extreme restrictions leads many women to ignore the areas in which they are exploited or discriminated against; it may even lead them to imagine that no women are oppressed" (Hooks, 1984, p. 5).

\section{Types of Feminism}

The understanding and analysis of oppression are central to feminist theories. Much of the work in the second wave of feminism focused on attempts to identify the nature of women's oppression. Theories may identify the lack of education, economic dependence, unequal political rights, or the need for control over sexuality as related to the nature of oppression. Theories address the causes of oppression as the cultural order, labor and economic relations, biological differences, political institutions, and women's own self-understanding. Feminist theory requires us to critically analyze what is happening in our social world from multiple contexts and provide strategies for the amelioration of adverse conditions that effect the lives of women (Kolmar \& Bartkowski, 2000). Though one central feminist theory has not evolved, basic principles are commonly given when describing feminism, including such concepts as valuing women and their experiences, identifying conditions that oppress women, changing society through advocacy, and recognizing that many factors, not just gender, impact a woman's actions and views (McCormick \& Bunting, 2002). The progress in feminism has been more focused on different types of feminism.

Feminism has evolved in different arenas rather than as one unified concept. The labels that define those arenas have varied. The most commonly used are eight separate feminist theories: black feminism, radical feminism, cultural feminism, lesbian feminism, liberal feminism, Marxist feminism, materialist feminism, and socialist feminism (Andermahr, Lovell, \& Wolkowitz, 1997; Evans, 1995). Some theories can be grouped due to similarities, but distinctions offer a broader critical lens of a myriad of political, social, economic, ethnic, and cultural contexts.

Black feminism focuses not only on women, but specifically on the struggles of black women (Kanneh, 1998). Collins (2000) saw the concern of black feminism as resisting oppression through empowerment, which entails understanding the intersection of racism and sexism. Black feminist thought insists "that both the changed consciousness of individuals and the social transformation of political and economic institutions constitute essential ingredients for social change" (Collins, 1991, p. 221). Black women face social practices within a historical context that represent a "unique matrix of domination characterized by intersecting oppressions" (Collins, 2000, p. 23).

Individual transformation involves acknowledging the historical structure of institutions of domination. The result of this understanding is a changed consciousness, which Collins (1991) believed necessary for social change. Black feminist analysis insists on understanding what it means to be a black woman in a racist patriarchy (Johnson, 1983).

Differences due to race, class, gender, sexuality, and religion are of distinct importance in many cultures and are "visible and palpable" (Collins, 1991, p. 23) for black women. Knowledge and consciousness as to how race, class, and gender 
represent interlocking systems and a sociohistorical context for that analysis is seen as absent in other feminisms (Collins, 1991).

Radical feminism attributes the oppression of women to men. Male power must be analyzed and understood and not reduced to other explanations, such as labor relations. Cultural feminism has been critiqued, because it provides moral grounding for men to make claims that they cannot help being oppressive. This logic takes a further turn, in that it is then likewise natural for women to be submissive (Ferguson, 1996).

Lesbian feminism focuses on establishing lesbians as a distinct group. Much like radical feminism, lesbian feminism sees the male agenda as dominant in the culture at-large (Andermahr, Lovell, \&Wolkowitz, 1997). Compulsory heterosexuality is challenged by lesbian feminism (Rich, 1986). It must be challenged, because compulsory heterosexuality is linked to the oppression of all women. Heterosexuality benefits men, in that it reflects male needs and fantasies, it controls women, and is linked to capitalism.

Liberal feminism focuses on rights for women, as in access to education, the right to vote, and economic independence, citizenship, and other issues of equality (Saulnier, 1996). Prescribed roles are challenged in that prescriptions lead to inequality. Many women benefit from the strategies of liberal feminism and its focus on the public lives of women; however, it has been critiqued for this very reason, in that it does not adequately address private issues, such as child care and poverty, to name a few (Saulnier).

Marxist feminism is focused on the emancipation of women via a concern for the production of labor in family life, as it is concerned with capitalism (Andermahr, Lovell, \&Wolkowitz, 1997). MacKinnon (1997) stated that, "Sexuality is to feminism what work is to Marxism: that which is most one's own, yet most take away" (p. 65). Marxist theory sees work as creating our social lives and creating what is of value: work creates who we are.

Material feminism relies on Marxist theory. The focus is on the material conditions of women's lives and their transformation. A central concern is for women to maintain a socialized and professional household. This could include adequate pay for professional labor related to childcare, cooking, cleaning, and other domestic labors that are often relegated to women (Donovan, 1993).

Socialist feminism is closely related to Marxist feminism, radical feminism, and materialist feminism (Andermahr, Lovell, \& Wolkowitz, 1997). Perhaps a distinguishing point is that socialism distinguishes between groups with regard to oppression and acknowledges that it takes different forms, depending on the context and particulars. Socialist feminism in the extreme demands the end of capitalism, property ownership, the emancipation of workers, and the ending of all forms of oppression (Evans, 1995).

Feminists seem to have a love/hate relationship with postmodernism. Postmodern feminism is perhaps the most difficult to characterize or define, because it is a story that is incomplete. Because postmodernism claims the end of grand narratives and totalizing truths, it is seen as problematic in that it appears blind to the affects of gender in relationship to oppression and the total- 
izing of women (Evans, 1995). At the same time, the rejection of grand narratives opens space for women to redefine "woman."

This discussion of feminist theories is not meant to be complete or serve as a conclusive explanation for any of the theories represented. Instead, it is meant to acknowledge the diversity and similarities among feminist theories.

The authors also sought to understand feminist theory as explored within the research literature. Besides the wide range of authors describing and conceptualizing feminist theory, some authors have strived to apply feminist theory to research agendas or even explore the basic components of feminist theory. We wanted to capture the research activity within our discussion. The next section of the article provides a review of the empirical studies conducted that involve feminist theory

\section{EMPIRICAL STUDIES ON FEMINIST THEORY DEVELOPMENT}

A systematic search of the literature was conducted using social science databases of abstracts (PsycINFO, social service abstracts, sociological abstracts, social work abstracts). The search used the words "feminist theory" and "research" as keywords or as words found in the abstract of an article. There were 1,174 citations listed using PsycINFO, social service abstracts, and sociological abstracts and 12 citations found in social work abstracts. A search was also done using the words: radical feminism, cultural feminism, lesbian feminism, liberal feminism, and Marxist feminism. Only empirical or theory-focused articles were included; articles that were on the general topic or did not strive to examine feminist theory were not included in this analysis. Book chapters and dissertations were not included, as they were not juried materials.

Of the 1,186 citations, there were only 17 articles that focused on empirical research that applied feminist theory to various settings and three articles that strived to summarize research on feminist theory and an area of practice. Table 1 summarizes the 17 articles. The three summary articles were on a feminist perspective on cardiovascular research (McCormick \& Bunting, 2002), feminist engagement with restorative justice (Daly \& Stubbs, 2006), and the application of feminist principles to therapy (Israeli \& Santor, 2000). The authors found numerous articles that speculated on applications and integration of feminist concepts, but these three articles strived to link empirical work with the feminist principles.

We wanted to develop a table that divided the articles according to the eight feminisms described earlier in this article, but the database searches found few or no studies identifying themselves by one of these types of feminism. Therefore, Table 1 is an alphabetical listing of studies, and any identification by type of feminism is included. The 17 articles show a diversity of applications of feminism. There were no articles found that described a feminist meta-theory. Snelling (1999) did strive, using Q-sort, to develop different perspectives on feminism but did not discuss the central components of a feminist theory. Most articles focused on applying a feminist lens to the various research agendas. For example, chemical dependence recovery (Pursley-Crotteau, 2001), heterosexist harassment (Szymanski, 2006), relationships facing dementia (Ward-Griffin et al., 2007), the relationship between sisters (Mize \& Pinjala, 2002), or inter-sibling violence 


\begin{tabular}{|c|c|c|c|}
\hline Author & Sample & Method & Findings \\
\hline Barns, 2003 & $\begin{array}{l}\text { Six } 14 \text { to } 15 \text {-year- } \\
\text { old young women }\end{array}$ & $\begin{array}{l}\text { Feminist interpretive } \\
\text { research to capture } \\
\text { how women negotiate, } \\
\text { construct, and resist } \\
\text { "the feminine." }\end{array}$ & $\begin{array}{l}\text { Women described how } \\
\text { femininity occurs within } \\
\text { the family, within them } \\
\text { selves, through mass } \\
\text { media, and through what } \\
\text { they wear. }\end{array}$ \\
\hline $\begin{array}{l}\text { Ciclitira, } \\
2004\end{array}$ & $\begin{array}{l}34 \text { women age } \\
23 \text { to } 52 \text { years }\end{array}$ & $\begin{array}{l}\text { A semi-structured, } \\
\text { taped interview with } \\
\text { discourse analysis of } \\
\text { transcripts; the focus } \\
\text { of study was on porn- } \\
\text { ography and feminist } \\
\text { politics. }\end{array}$ & $\begin{array}{l}\text { A range of diverging } \\
\text { views was given, with } \\
\text { advocacy, sexual free } \\
\text { dom, and politics as the } \\
\text { key issues discussed. }\end{array}$ \\
\hline Cook, 2006 & $\begin{array}{l}\text { Observed } 12 \\
\text { diversionary } \\
\text { conferences and } \\
\text { interviewed } 16 \\
\text { conference } \\
\text { coordinators }\end{array}$ & $\begin{array}{l}\text { Observational field } \\
\text { notes during or after } \\
\text { each conference. }\end{array}$ & $\begin{array}{l}\text { Four themes emerged: } \\
\text { offenders' claims about } \\
\text { self and motive, mothers } \\
\text { as responsible and vul- } \\
\text { nerable, fathers as silent } \\
\text { partners, and community } \\
\text { representatives and facil- } \\
\text { itators challenging or } \\
\text { reinforcing hierarchies. }\end{array}$ \\
\hline $\begin{array}{l}\text { Denny, } \\
1994\end{array}$ & $\begin{array}{l}\text { Ten women } \\
\text { (seven women } \\
\text { alone and three } \\
\text { couples) }\end{array}$ & $\begin{array}{l}\text { A semi-focused } \\
\text { interview of seven } \\
\text { women alone and } \\
\text { three women with } \\
\text { partners; the focus } \\
\text { was on understanding } \\
\text { and interpreting their } \\
\text { experiences with in- } \\
\text { vitro fertilization (IVF). }\end{array}$ & $\begin{array}{l}\text { Women had diverse } \\
\text { views of pro-natalism, } \\
\text { their experience, power, } \\
\text { and control while going } \\
\text { through IVF, and how } \\
\text { these views conform or } \\
\text { diverge from radical } \\
\text { feminism. }\end{array}$ \\
\hline $\begin{array}{l}\text { Gentry et } \\
\text { al., } 2005\end{array}$ & $\begin{array}{l}45 \text { African } \\
\text { American women } \\
\text { at risk for HIV } \\
\text { infection }\end{array}$ & $\begin{array}{l}\text { Ethnographic } \\
\text { interviews aimed at } \\
\text { understanding the } \\
\text { context of women } \\
\text { applying HIV risk- } \\
\text { reduction strategies. } \\
\text { Participant observation } \\
\text { and geographical } \\
\text { mapping were also } \\
\text { done. Coding was } \\
\text { done using black } \\
\text { feminist themes. }\end{array}$ & $\begin{array}{l}\text { Four groups were identi- } \\
\text { fied (street women [sub- } \\
\text { groups of absolute } \\
\text { homeless, hustling } \\
\text { homeless, and rooming } \\
\text { housed] and house } \\
\text { women) as the women } \\
\text { felt their living arrange- } \\
\text { ments were key to HIV } \\
\text { risk. }\end{array}$ \\
\hline $\begin{array}{l}\text { Harnois, } \\
2005\end{array}$ & $\begin{array}{l}1,619 \text { women } \\
\text { from a } 1996 \\
\text { general social } \\
\text { survey }\end{array}$ & $\begin{array}{l}\text { Focused on multi- } \\
\text { racial feminist theory } \\
\text { using key survey } \\
\text { questions answered } \\
\text { by white and black } \\
\text { women in structural } \\
\text { equation modeling. }\end{array}$ & $\begin{array}{l}\text { Factor analysis showed } \\
\text { more educated white wom- } \\
\text { en embraced feminism } \\
\text { and gay/lesbian issues; } \\
\text { weaker predictors for black } \\
\text { women embracing femin- } \\
\text { ism or gay/lesbian issues. }\end{array}$ \\
\hline
\end{tabular}




\begin{tabular}{|c|c|c|c|}
\hline Author & Sample & Method & Findings \\
\hline $\begin{array}{l}\text { Hoffman } \\
\text { et al., } 2005\end{array}$ & $\begin{array}{l}651 \text { college } \\
\text { students residing } \\
\text { with a sibling in } \\
\text { his or her senior } \\
\text { year of high school } \\
\text { and both parents } \\
\end{array}$ & $\begin{array}{l}\text { Survey assessing sibling } \\
\text { violence, parent-child } \\
\text { interaction, gender, } \\
\text { and gender inequalities. }\end{array}$ & $\begin{array}{l}70 \% \text { had at least one } \\
\text { episode of sibling vio- } \\
\text { lence, males were more } \\
\text { violent, males favored a } \\
\text { gendered division of } \\
\text { chores more than females. }\end{array}$ \\
\hline $\begin{array}{l}\text { Mize \& } \\
\text { Pinjala, } \\
2002\end{array}$ & $\begin{array}{l}36 \text { sister teams } \\
\text { ranging in age } \\
\text { from } 24 \text { to } 85 \text { years } \\
\text { of age }\end{array}$ & $\begin{array}{l}\text { With a combined } \\
\text { feminist/narrative } \\
\text { theoretical approach in } \\
\text { a qualitative format, } \\
\text { the researchers asked a } \\
\text { series of conversational } \\
\text { questions to biological/ } \\
\text { adoptive adult sisters, } \\
\text { together, regarding their } \\
\text { various perspectives on } \\
\text { interactions in their } \\
\text { original families. }\end{array}$ & $\begin{array}{l}\text { The results showed that } \\
\text { interviewing sisters } \\
\text { together provides a pow- } \\
\text { erful, creative process } \\
\text { that allows for an impor- } \\
\text { tant understanding of the } \\
\text { potent mix of anger, love, } \\
\text { competitiveness, and } \\
\text { protectiveness that sis- } \\
\text { ters reflect in their histor- } \\
\text { ical views as well as in the } \\
\text { the current research } \\
\text { interview interaction. }\end{array}$ \\
\hline $\begin{array}{l}\text { Pearson, } \\
2007\end{array}$ & $\begin{array}{l}24 \text { women of color } \\
\text { in New York City } \\
\text { or Los Angeles }\end{array}$ & $\begin{array}{l}\text { Ethnographic interviews } \\
\text { focused on support or } \\
\text { denial of multicultural } \\
\text { feminism as dialogue } \\
\text { and communication } \\
\text { among women of color. }\end{array}$ & $\begin{array}{l}\text { Women of color did not } \\
\text { see that multicultural } \\
\text { feminism was helpful as } \\
\text { a dialogue; a specific rea- } \\
\text { son to talk is more } \\
\text { important, especially } \\
\text { when focus is on power } \\
\text { and dominance issues. }\end{array}$ \\
\hline $\begin{array}{l}\text { Prindville, } \\
2000\end{array}$ & $\begin{array}{l}30 \text { women holding } \\
\text { public office in } \\
\text { New Mexico }\end{array}$ & $\begin{array}{l}\text { Qualitative data from } \\
\text { field interviews focused } \\
\text { on whether they } \\
\text { identify themselves or } \\
\text { their policy goals as } \\
\text { feminist. }\end{array}$ & $\begin{array}{l}33 \% \text { identified self as } \\
\text { feminist, } 40 \% \text { rejected } \\
\text { outright the label "femi- } \\
\text { nist," but most favor poli- } \\
\text { cies and programs pro- } \\
\text { moting equality. }\end{array}$ \\
\hline $\begin{array}{l}\text { Pursley- } \\
\text { Crotteau, } \\
2001\end{array}$ & 19 women & $\begin{array}{l}\text { Using the feminist } \\
\text { perspective and } \\
\text { grounded theory } \\
\text { method, women who } \\
\text { were participating or } \\
\text { interfacing with a } \\
\text { psychiatric-obstetrical } \\
\text { clinic within a maternal } \\
\text { and infant project in a } \\
\text { large Southeastern city } \\
\text { were interviewed. }\end{array}$ & $\begin{array}{l}\text { Staying clean was the } \\
\text { social-psychological } \\
\text { problem generated from } \\
\text { the data. Becoming tem- } \\
\text { perant was identified as } \\
\text { the process by which the } \\
\text { women managed to stay } \\
\text { clean. }\end{array}$ \\
\hline
\end{tabular}




\begin{tabular}{|c|c|c|c|}
\hline Author & Sample & Method & Findings \\
\hline $\begin{array}{l}\text { Skelton, } \\
2005\end{array}$ & $\begin{array}{l}22 \text { academic } \\
\text { women (10 ages } \\
40-50 ; 12 \text { ages } 29- \\
34) \text { in English and } \\
\text { Welsh universities }\end{array}$ & $\begin{array}{l}\text { Semi-structured one- } \\
\text { hour interviews later } \\
\text { recorded with data } \\
\text { reviewed for patterns } \\
\text { and themes; themes } \\
\text { were linked to material- } \\
\text { ist feminism. Partici- } \\
\text { pants sent ahead a list } \\
\text { of proposed areas of } \\
\text { discussion that focused } \\
\text { on what factors shaped } \\
\text { and developed their } \\
\text { careers. }\end{array}$ & $\begin{array}{l}\text { Both generations of aca- } \\
\text { demics experienced mas- } \\
\text { culinized, organizational } \\
\text { structures that marginal- } \\
\text { ized or subordinated } \\
\text { them whether the super- } \\
\text { visor was male or female. }\end{array}$ \\
\hline $\begin{array}{l}\text { Snelling, } \\
1999\end{array}$ & $\begin{array}{l}59 \text { women ages } 17- \\
73 \text { ( } 85 \% \text { white, } 85 \% \\
\text { heterosexual) }\end{array}$ & $\begin{array}{l}\text { Q-methodological } \\
\text { study with } 50 \text { Q-sort } \\
\text { items reflecting per- } \\
\text { spectives on feminism; } \\
\text { women sorted four } \\
\text { cards into extreme pos- } \\
\text { itions, five cards into } \\
\text { middle positions, and } \\
\text { six cards in neutral pos- } \\
\text { itions. Nine women had } \\
\text { follow-up telephone } \\
\text { interviews. Factor } \\
\text { analysis was done on } \\
\text { data from Q-sort. }\end{array}$ & $\begin{array}{l}\text { Six factors were derived } \\
\text { from the factor analysis: } \\
\text { radical/lesbian/liberal } \\
\text { antiracist perspective, } \\
\text { feminist perspective, } \\
\text { humanist perspective, } \\
\text { conservative position } \\
\text { with some anti-feminist } \\
\text { elements, post-feminist } \\
\text { viewpoint, and non- } \\
\text { labeled position. Many } \\
\text { women had Q-sorts } \\
\text { loaded on more than one } \\
\text { factor. Thus, the taxo- } \\
\text { nomic system of femin- } \\
\text { nism was not yet ready, } \\
\text { but the Q-sort research } \\
\text { was promising. }\end{array}$ \\
\hline $\begin{array}{l}\text { Szymanski, } \\
2006\end{array}$ & 143 lesbian women & $\begin{array}{l}\text { This survey included } \\
\text { several scales on } \\
\text { heterosexist harassment } \\
\text { and rejection. }\end{array}$ & $\begin{array}{l}\text { Harassment and rejec- } \\
\text { tion connected to dis- } \\
\text { tress in lesbians. }\end{array}$ \\
\hline $\begin{array}{l}\text { Wang et al., } \\
1996\end{array}$ & $\begin{array}{l}62 \text { Chinese women } \\
\text { age } 18-56 \text { years }\end{array}$ & $\begin{array}{l}\text { These women taught } \\
\text { photo novella (using } \\
\text { cameras to show condi- } \\
\text { tions and issues in their } \\
\text { villages; this program } \\
\text { was part of larger com- } \\
\text { munity empowerment } \\
\text { program. No research } \\
\text { methodology was used } \\
\text { in this article, just } \\
\text { anecdotes. }\end{array}$ & $\begin{array}{l}\text { Women used photo- } \\
\text { graphs to show condi- } \\
\text { tions and advocate for } \\
\text { health improvements. } \\
\text { The main points were to } \\
\text { empower women, } \\
\text { increase knowledge on } \\
\text { health status in rural } \\
\text { communities and influ- } \\
\text { ence policymakers on the } \\
\text { greatest needs. These } \\
\text { authors advocated that } \\
\text { the program reflects a } \\
\text { feminist approach to } \\
\text { change. }\end{array}$ \\
\hline
\end{tabular}




\begin{tabular}{|c|l|l|l|}
\hline \multicolumn{1}{|c|}{ Table 1: Research Studies on Feminist Theory (cont.) } \\
\hline Author & \multicolumn{1}{|c|}{ Sample } & \multicolumn{1}{c|}{ Method } & \multicolumn{1}{c|}{ Findings } \\
\hline $\begin{array}{l}\text { Ward-Griffin } \\
\text { et al., } 2007\end{array}$ & $\begin{array}{l}15 \text { mother- } \\
\text { daughter dyads } \\
\text { facing dementia }\end{array}$ & $\begin{array}{l}\text { Two individual } \\
\text { interviews "guided } \\
\text { by socialist-feminist } \\
\text { theory." }\end{array}$ & $\begin{array}{l}\text { Four types of relation- } \\
\text { ships (custodial, combat- } \\
\text { ive, cooperative, cohe- } \\
\text { sive) connected with } \\
\text { emotion focus and } \\
\text { resource provision. }\end{array}$ \\
\hline Wilson, 2004 & 4 social workers & $\begin{array}{l}\text { Single, indepth inter- } \\
\text { views with each worker, } \\
\text { and feminist discourse } \\
\text { analysis was chosen as } \\
\text { the method of text inter- } \\
\text { pretation. }\end{array}$ & $\begin{array}{l}\text { Three dominant themes } \\
\text { emerged from the inter- } \\
\text { views. They were "control } \\
\text { and perfection," "femi- } \\
\text { ninity," and "self-destruc- } \\
\text { tion/self-preservation." }\end{array}$ \\
\hline
\end{tabular}

(Hoffman et al., 2005) were foci of articles cited in this review. The articles seemed to acknowledge feminist theory as important, but mainly as a lens to explore their topic of interest. Thirteen studies used qualitative methodology, while four studies used quantitative methodology.

The most intriguing part of our review was the findings of the studies. Oppression, power and control, harassment, and masculinized environments still occur (Denny, 1994; Gentry et al., 2005; Hoffman et al., 2005; Pearson, 2007; Skelton, 2005; Szymanski, 2006; Wang et al., 1996). Sometimes oppression is not gender-specific but occurs regardless of gender in supervisory positions (Skelton, 2005). Many women do not identify themselves as feminist but still advocate feminist principles (Prindville, 2000). Some women of color do not embrace feminism to be as important as focusing on power and dominance issues (Harnois, 2005; Pearson, 2007). Using feminism as a lens to conduct research allows researchers to explore a better understanding of women's views and experiences when they face a wide range of issues (pornography, incarceration, in-vitro fertilization, homelessness, family violence, child rearing, academia, rural communities, dementia). In other words, the use of feminism as a guide in research is a tool that has wide-ranging utility.

The greatest disappointment was the dearth of research actually focusing on refining feminist theory. Where were the studies that asserted the crucial components of feminist theory or sought to empirically test those components? Where were the studies that sought to add the additional confirmation of existing feminist theory? We recognize that there are strong voices of post-modernist view that would say that empirical research is not required to value a theoretical discussion. We readily acknowledge that there is utility to the numerous articles that discuss feminism. However, we recognize that post-positivist advocates are also valuable and that empirical research is a part of a collective discussion of feminist theory. We were surprised by the absence of critical scholarship on feminist theory development. 


\section{IMPLICATIONS FOR SOCIAL WORK}

\section{Feminist Theory and Social Work Practice}

Bergh, 1995). Feminist principles are presented as a challenge to privilege. Who benefits from privileges that serve as barriers to quality of life for certain groups who bear social cost is a question that feminist social workers raise as an affront to dominance. Feminist theories are presented as a threat to the dominant social order (Saulnier, 1996).

Feminist social work practitioners rely on theory to challenge the pathologizing discourses about women, inequalities, and oppression. Practitioners are asked to critically examine feminist theory in order to provide a suitable fit for a broad range of problems experienced by women (Saulnier, 1996).

Van Den Bergh (1995) identified principles or ideas for feminist social work practices that are specifically related to postmodernism. She views postmodernism as an epistemological framework.

First is "partnerships rather than domination" (p. xv). This calls for relationships that build community. Practices that support hierarchy give rise to false dichotomies-a practice "inherent in sex role stereotyping" (p. xvi). Second, "Local rather than universal truths" (p. xvii) foster partnerships in knowledge construction. Knowledge production is the result of reflection and collaboration. Third, the local construction of knowledge has specific implications for social work interventions. Cultural meanings provide the context for social work practice. Fourth, feminist social work calls for a "critical mass" (p. xvii) around situations requiring social change. "Establishing community meanings" (p. xviii) or a group of people who share similar realities constitutes a critical mass in order to address social concerns within a network of support. And, fifth, Van Den Bergh (1995) identified the deconstruction and reconstruction of knowledge. Deconstruction is utilized to uncover knowledge "phallacies" (p. xix) by recovering knowledge that has been decentered by grand theories. Reconstruction refers to a restorying of knowledge that allows for the inclusion of marginalized voices, resulting in a more inclusive story.

Next, Van Den Bergh (1995) asserted the importance of socially constructed knowledge. She pointed to feminists' concern with consciousness-raising as a form of knowledge production, which includes the life experiences of women. Voice-naming reality is empowering, which brings forward the importance of her last identified idea for social work practitioners-the "link between knowledge and power" (p. xxiii). She linked those who control society with those who are privileged to establish what is known. It is crucial for social workers to make space for voices that have been marginalized by hierarchies of expertness in order to have a voice.

The challenge of third-wave feminism claims is to go beyond rights and equity, although these are notable challenges in a global world. The post-structuralist agenda, articulated 10 years ago, is to "remain aware of the complex ways that power, oppression, and resistance work in a media-saturated global economy so that what at first glance looks like progress might not be the change we most need, and what looks like regression might be progressive" (Heywood \& Drake, 1997, p. 23). 
Pollio (2000) advocates for three principles of practice: understand the social context of the individual as including personal, political, and historical factors; include the strengths and experiences that women in oppressed populations have, and recognize that political correctness can be a form of oppression. Pollio cautions against focusing on labels rather than respecting each person's individual uniqueness.

Israeli and Santor (2000) review the basic components of feminist therapy, including empirical evidence of the effectiveness of each component. They see the basic components as consciousness raising, social and gender role analysis, resocialization, and social activism.

Promoting feminist principles for social work practice is a critical priority for the future. Women face issues of equity related to economics, poverty, healthcare, childcare, and so forth. The analysis of these issues must also include race, ethnicity, socio-economic status, and how these play out on a global landscape. Strategies to create a practice framework that empowers and honors women are the challenge for the future. The research reviewed in the article indicates that oppression and masculinized environments still occur. Social work must take the lead in the advocacy and service needed for these issues.

\section{Feminist Theory and Research Initiatives}

Social work scholarship often feeds advances in social work practice technology. Currently, there are many scholars discussing and conceptualizing feminist theory as it applies to practice principles, policy initiatives, and as a lens when conducting research. Virtually no scholars are testing feminist theory to move the theory from discussed theory to confirmed theory. No scholars are refining feminist theory, describing the components of the theory, and showing empirical evidence that demonstrates that the components fit together as hypothesized. No scholars are either advocating for one meta-theory of feminism or showing why multi-cultural feminist theory is different from radical feminist theory. In summary, the absence of theory development work is stunning.

What should happen? Journals that specialize in feminist issues should begin a series of special issues on feminist theory development. Perhaps a special issue for each type of feminism would be helpful. Scholars with expertise in theory development should prioritize feminist theory. Methodology critics should apply the same scientific rigor to feminist theory as they would any other theory. Scholars should collaborate, by developing multi-site projects with diverse populations and central research agendas. Debates should rage about how to honor the feminist view while still demanding scientific rigor. The attention, energy, and findings of these multiple efforts would prompt significant advances and clarity to feminist theory. Advocacy work and practice guidelines would continue and be informed by the scholarship.

\section{CONCLUSION}

This article has explored the diversity of views on feminism and how researchers have applied feminist theory as a lens to conduct their research. Our review of the feminist literature uncovered more than a dozen textbooks and more than a thou- 
sand literature citations. Much discussion and conceptualization about feminist issues appears in the literature, especially on the importance of advocacy and empowerment. However, there is scant empirical research on feminist theory and only one article focusing on feminist theory itself. No articles were found that sought to define feminist theory, then tested the components of the theory.

Feminism as a movement and advocacy issue is vibrant, diverse, and wide-ranging. Feminism as a focus within social work practice is often discussed and a complex issue to incorporate into practice principles. With the conditions of oppression, lack of power, or lack of control, a male-dominated culture still exists. Projects that identify, expose, and remove those conditions are still being developed (see for example, the creative use of photographs in the hands of poor rural Chinese women as collating evidence of conditions and advocating for change as described in Wang et al. [1996]). Research informed by feminist views continues to enlighten us on a very diverse set of conditions from pornography, to dementia, to diversionary conferences.

The challenge for the reader is to be a discontent consumer. There are many avenues for learning about feminism, and the importance of advocating for feminist principles is more important today than 10 years ago. The mission for social workers is increasingly vital to the welfare of women and society in general. However, the reader should also be discontent, as scholars need to prioritize basic theory development research on feminist theory and ensure that our research leads to evidence-based practice guidelines. The lack of scholarship hampers getting the best answers to the reader regarding applying feminist theory to practice. We only hope that the next 10 years show a renaissance of academic rigor with scholarly articles as outcomes. Time will tell.

\section{References}

Andermahr, S., Lovell, T., \& Wolkowitz, C. (1997). A concise glossary offeminist theory. London: Arnold.

Barns, A. (2003). Social work, young women, and femininity. Affilia, 18(2), 148-164.

Chinn, P.L., \& Wheeler, C.E. (1985). Feminism and nursing: Can nursing afford to remain aloof from the women's movement? Nursing Outlook, 33(2), 74-77.

Ciclitira, K. (2004). Pornography, women and feminism: Between pleasure and politics. Sexualities, 7(3), 281-301.

Collins, P. (2000). Black feminist thought: Knowledge, consciousness, and the politics of empowerment $\left(2^{\text {nd }}\right.$ ed.). New York: Routledge.

Cook, K.J. (2006). Doing difference and accountability in restorative justice conferences. Theoretical Criminology, 10(1), 107-124.

Denny, E. (1994). Liberation or oppression? Radical feminization and in vitro fertilization. Sociology of Health and Illness, 16(1), 62-80.

Donovan, J. (1993). Feminist theory: The intellectual traditions of American feminism. New York: Continuum.

Duran, J. (1998). Philosophies of sciencelfeminist theories. Boulder, CO: Westview Press.

Evans, J. (1995). Feminist theory today: An introduction to second-wave feminism. London: Sage. 
Ferguson, A. (1996). Can I choose who I am? And how would that empower me? Gender, race, identities and the self. In A. Garry \& M. Perarsall (Eds.), Women, knowledge, and reality: Exploration in feminist philosophy (pp. 108-126). New York: Routledge.

Flax, J. (1990). Postmodernism and gender relations in feminist theory. In L. Nicholson (Ed.), Feminism/postmodernism (pp. 39-62). London: Routledge.

Flax, J. (1999). Women do theory. In M. Pearsall (Ed.), Women and values: Readings in recent feminist philosophy (pp. 9-13). Belmont, CA: Wadsworth.

Fonow, M., \& Cook, J.A. (Eds). Beyond methodology: Feminist scholarship as lived research. Bloomington, IN: Indiana University Press.

Gentry, Q.M., Elifson, K., \& Sterk, C. (2005). Aiming for more relevant HIV risk reduction: A black feminist perspective for enhancing HIV intervention for low-income African American women. AIDS Education and Prevention, 17(3), 238-252.

Hesse-Biber, S. (2002). Feminism and interdisciplinarity. In J. DiGeorgio-Lutz (Ed). Women in higher education. (pp. 57-66). Westport, CT: Praeger.

Hesse-Biber, S., Gilmartin, C., \& Lydenberg, R. (Eds.) (1999). Feminist approaches to theory and methodology: An interdisciplinary reader. New York: Oxford University Press.

Hesse-Biber, S.N., Leavy, P., \& Yaiser, M.L. (2004). Feminist approaches to research as a process: Reconceptualizing epistemology, methodology, and method. In S.N. Heese-Biber \& M.L. Yaiser (Eds). Feminist perspectives on social research. (pp. 3-26). New York: Oxford University Press.

Heese-Biber, S.N., \& Yaiser, M.L. (Eds). Feminist perspectives on social research. New York: Oxford University Press.

Heywoood, L., \& Drake, J. (Eds.) (1997). Third wave agenda: Being feminist, doing feminism. Minneapolis, MN: University of Minnesota Press.

Hooks, B. (1984). Feminist theory: From margin to center. Boston: South End Press.

Johnson, E. (1983). Reflections on black feminist therapy. In B. Smith (Ed.), Home girls: A Black feminist anthology (pp. 320-324). New York: Kitchen Table-Women of Color Press.

Kanneh, K. (1998). Black feminisms. In S. Jackson \& J. Jones (Eds.), Contemporary feminist theories. (pp. 8697). New York: New York University Press.

Kolmar, W.K., \& Bartkowski, F. (2000). Feminist theory: A reader. Mt. View, CA: Mayfield Publishing Company.

Mac Kinnon, C. (1997). Feminism, Marxism, method, and the state: An agenda for theory. In D. Meyers (Ed.), Feminist social thought: A reader (pp. 65-91). New York: Routledge.

Mize, L.K., \& Pinjala, A. (2002). Sisterhood narratives: Opportunities in connections. Journal of Feminist Family Therapy, 14(1), 21-51.

Pursley-Crotteau, S. (2001). Perinatal crack users becoming temperant: The social psychological processes. Health Care for Women International, 22(1-2), 49-66.

Rich, A. (1986). Blood, bread, and poetry. New York: W.W. Norton.

Saulnier, C. (1996). Feminist theories and social work: Approaches and application. New York: Haworth Press.

Van Den Bergh, N. (Ed.). (1995). Feminist practice in the $21^{\text {st }}$ century. Washington, D.C.: NASW Press.

Wilson, J. (2004). Beyond psychiatry: How social workers conceptualise women and self-starvation. Australian Social Work, 57(2), 150-160.

\section{Author's Note:}

Address correspondence to: Kathy Lay, Ph.D., School of Social Work, 902 West New York Street, Indianapolis, IN 46202-5156, USA. e-mail: klay@iupui.edu. 